\author{
Journal of International Business Research and \\ Marketing \\ Volume 2, Issue 4, 2017 \\ journal homepage: www.researchleap.com
}

\title{
Place Attractiveness and Events: From Economic Impacts to Place Marketing
}

\author{
${ }^{1}$ Christophe Alaux, ${ }^{2}$ Léa Boutard \\ ${ }^{I}$ Senior Lecturer, Director of IMPGT (Public Management and Territorial Governance Institute), Director of Chair : Regional attractiveness and new place marketing. \\ Aix Marseille University, CERGAM, Puyricard, France. \\ ${ }^{2}$ Phd Student, (IMPGT : Public Management and Territorial Governance Institute) Aix Marseille University, CERGAM, Puyricard, France.
}

\section{ABSTRACT}

\author{
2017 Research Leap/Inovatus Services Ltd. \\ All rights reserved.
}

DOI: $10.18775 /$ jibrm.1849-8558.2015.24.3004 URL: http://dx.doi.org/10.18775/jibrm.1849$\underline{8558.2015 .24 .3004}$

Keywords:

Place Marketing, Place attractiveness, Image,

Identity, Events

\begin{abstract}
The research aims at studying the interactions between the concepts of attractiveness, place marketing and events through the prism of image and identity in a medium-long term vision. In a holistic approach, we will study the transversality of the impacts such as social, economic, touristic, effects and the interactions between the image and identity of places. The understanding of what goes beyond short-term economic impact could contribute to foster a long-term attractiveness and an endogenous development.
\end{abstract}

\section{Introduction}

Place attractiveness is a major concern for all administrative levels. To foster the local economy, places tend to attract people, investments and to maintain them. The holistic approach of place attractiveness embodies the social, economic and touristic aspects of attractiveness.

The organization of mega-events (Getz, 2008, 2007; Ritchi, Crouch 2000) or small-scale events generate economic, touristic, social and urban impacts. Sports, cultural and business events are a value added for the place.

In a context of competition between places (Warnaby, al. 2008), city managers develop hallmark events with high-value and image added, which are supposed to generate a strong media impact. These event strategies were originally developed by the major capitals to provide international exposure and thus enhance their competitiveness and attract investors and tourists (Castells, 1989). These events help to strengthen place attractiveness (Kavaratzis, Ashworth, 2008; Canali, D'Angella, 2009).

Place attractiveness is the capacity of "a territory to spread, to promote its offer and to attract on an occasional or permanent basis persons, events or capitals" (Regional attractiveness and new place marketing; Hatem, 2005). Place Marketing involves "all the process of creation, communication and delivering of value to develop place attractiveness and the hospitality of a territory" (Regional attractiveness and new place marketing). Place Marketing is "the scientific discipline and field of practice responsible for developing and implementing a managerial process that assists places to achieve their objectives by adopting a market-oriented philosophy" (European Place Marketing Institute,
2015). The relations between these concepts of attractiveness, place marketing (image and identity) and events would be investigated.

First of all, events have an immediate economic and touristic impact, these types of impact are the more easily appreciable. Events also have an effect on the image and identity of places, but these impacts are more difficult to measure.

In a second time, this relationship would be analyzed in a more interactive way in a medium-long term. The interactions of image and "constellations events" can transform place identity. Furthermore, an endogenous capitalization of interactions can lead to creating "event constellations" or event "eco-system". Constellations are formed by the development of companies, organizations, research centers, education projects around recurring events such as the festival of lights in Lyon or the Mobile World Congress in Barcelona.

In the third time, we will see three case studies and how interactions are both exogenous and endogenous. The ability to develop activities around the event is one of the key success factors of an event-based attractiveness policy.

\section{Value Creation Over the Short Term}

Events have an immediate economic and touristic impact over the short term. Researchers focused on the economic and touristic effects and on the creation of a tool to evaluate these impacts.

\subsection{Economic Impact Prevails}

The concept of investment multipliers is used to evaluate the economic impacts of the events. For 1 Euro invested, the benefits of the events can 
be multiplied by an average of 6 or 8 . The evaluation of the economic impact over the territory legitimizes the initial investment. Nevertheless, the use of inappropriate multipliers can overstate the economic impacts of these events (Siegfried, Zimbalist, 2000).

Table 1: Economic impacts by type of events

\begin{tabular}{|c|c|c|}
\hline $\begin{array}{l}\text { Dimension } \\
\text { of events }\end{array}$ & Type of events & For each $€$ investment \\
\hline \multirow{8}{*}{$\begin{array}{l}\text { Local/regio } \\
\text { nal event }\end{array}$} & Cultural event in general & $4-8 €^{1}$ \\
\hline & Festival d'Avignon & $5-6 €^{2}$ \\
\hline & Eurockéennes de Belfort & $6,9 €^{3}$ \\
\hline & Festival de Cannes & $10 €^{4}$ \\
\hline & Business event & $8-10 €$ \\
\hline & Public conferences & $8 €^{5}$ \\
\hline & Professional conferences & $10 €$ \\
\hline & $\begin{array}{l}\text { Val de Lorraine Classic } \\
2011\end{array}$ & $2,6 €^{6}$ \\
\hline \multirow{4}{*}{$\begin{array}{l}\text { Mega- } \\
\text { event: } \\
\text { national/int } \\
\text { ernational } \\
\text { level }\end{array}$} & $\begin{array}{l}\text { European Capital of } \\
\text { culture in general }\end{array}$ & $6-8 €$ \\
\hline & $\begin{array}{l}\text { Marseille Provence } 2013 \\
\text { European Capital Culture }\end{array}$ & $6 €^{7}$ \\
\hline & $\begin{array}{ll}\text { Lille } 2004 & \text { European } \\
\text { Capital Culture } & \end{array}$ & $8 €^{8}$ \\
\hline & Euro 2016 France & $1,25 €^{9}$ \\
\hline
\end{tabular}

Most of the impacts' assessment is focused on the economic aspect of the events over the short term. Studies of ex-ante and ex-post impact seek to legitimate initial investments by calculating the event investments' multiplier. Impacts in terms of image and social effects are more difficult to measure. Events have not only economic spin-offs over the short term, but they also have an impact on the image of places.

\footnotetext{
${ }^{1}$ Speech of Ministry of Culture and Communication, August 2011.

${ }^{2}$ Around 23 million according to the Centre Norbert Elias - University of Avignon
}

${ }^{3}$ The cultural and creative Industries in France study, economic panorama EY - 2016

${ }^{4}$ Around 200 million according to the Report Industries culturelles et créatives en France, panorama économique EY - 2016

${ }^{5}$ Study Médiamétrie for UNIMEV - Direction Générale des Entreprises (Ministère de l'Economie) - CCI Paris Ile-de-France - CEP

${ }^{6}$ Report of Conseil de Pays du Val de Lorraine (2011)

${ }^{7}$ Around 600 millions according to the organizers of Marseille Provence 2013

\section{${ }^{8}$ Organizers of Lille 2004 (David Fusiller)}

${ }^{9}$ Around 1,222 billions of euros: report of the Centre de Droit et d'Economie du Sport et de Keneo on the economic and social impact $e x$ ante of UEFA EURO 2016 (2014)

\footnotetext{
${ }^{10}$ Meetings, incentives, conferencing, exhibitions
}

\subsection{The Diversity of Impacts}

These event strategies were originally developed by the major capitals to provide international exposure and thus enhance their competitiveness and attract investors and tourists (Castells, 1989).

Events impact the external image and can transform the mental representation we have of a place. Furthermore, social impacts can be strong, especially for events such as European Capital of Culture. Urban infrastructure can also be subject to change because of heavy investments (new infrastructure, a program of renovation).

On the one hand, mega-events significantly improve tourist and economic attractiveness of a place at an international level. On the other hand, local and regional events have an impact on the territory's external and internal image. They both contribute to the dynamism of the residential economy through their impact on domestic tourism.

Focusing on the event category (local/regional vs. mega-events) and the nature of the events (cultural, sporting, MICE) allows us to identify the strength of the different impacts. Mega-events have predominant effects on the economic and tourist attractiveness at an international level, and on the external image and urban infrastructure that they require. Moreover, their social impact is not a priority except for European capitals of culture. The events at the local or regional level have a less structuring role. They contribute to an evolution of the area's image internally and sometimes externally. They contribute to the dynamism of the residential economy through their impact on domestic tourism.

Table 2: Impacts of events on place attractiveness

\begin{tabular}{|c|c|c|c|c|}
\hline $\begin{array}{l}\text { Ympacts } \\
\text { Events }\end{array}$ & Image & $\begin{array}{l}\text { Economic } \\
\text { / Touristic }\end{array}$ & Social & Urban \\
\hline \multicolumn{5}{|c|}{ Mega-event : national / international level } \\
\hline Sport & Strong & Strong & Weak & Strong \\
\hline Cultural & Strong & Strong & Medium & Strong \\
\hline MICE & Strong & Strong & Weak & Weak \\
\hline \multicolumn{5}{|c|}{ Event : local / regional level } \\
\hline Sports & Medium & $\begin{array}{l}\text { Medium / } \\
\text { Strong }\end{array}$ & Medium & Weak \\
\hline Cultural & Strong & $\begin{array}{l}\text { Medium / } \\
\text { Strong }\end{array}$ & Medium & Weak \\
\hline MICE & Weak & Strong & Weak & Weak \\
\hline
\end{tabular}

Over the medium-long term, the place image is interacting with the place identity and creates not only economic value.

\section{Interaction and Value Creation Over the Medium-long Term}

A holistic vision encompasses all kinds of events effects to understand the interactions between places and events in a medium-long term vision. The interaction between event attractiveness and territorial attractiveness is shaping the images and identities of places.

\subsection{Interactions Between Place, Image, and Identity}

Events shape the attractiveness of places by enhancing their physical assets, images, and identities. The territorial identity will also, in turn, influence the nature of events. 
The place identity is referring to a form of social identity characterized by features that mark the affiliation of an individual to a place (Parmentier, Rolland, 2009). Keating (1998) defines territorial identity with a cognitive (the knowledge of a place and its geographic limits), an effective (a shared identity) and an instrumental aspect (a mobilization for a collective action).

Chamard et al. (2013) combine similar components to define the image of a place: an affective (the feeling), a cognitive (the knowledge) and a behavioral aspect (the reason to shift to a place). This territorial identity constitutes an antecedent of the territory brand image based on user's mental representations (Kavaratzis, Hatch, 2013).

A famous event can be part of this territorial identity. As shown in the next figure on relationship place marketing, place identity is the results of interactions between internal stakeholders and the place. It is an antecedent of place image that can be perceived by internal or external stakeholders.

Figure 1: Place Relationship Marketing, image, and identity

\begin{tabular}{|c|c|c|}
\hline Place \\
Relationship \\
Marketing
\end{tabular}

\subsection{From Economic Impacts to Interactive Event Constellations}

Over the long term, all the positive effects of events can contribute to a more endogenous growth through the development of "event constellations" in the territory.

Depending on the strength of the image of the event and its interactions with the image of the place, the identity of the territory can also be transformed. The territorial anchorage of the event would be even more reinforced over the long term.

Enhancing the endogenous potential of events leads to create ecosystems or event constellations. "Event constellations" are formed by the development of activities, companies, organizations, research and educational programs around the topic of events. Interactions in these constellations are both exogenous and endogenous. The ability of a territory to develop activities around the event is one of the key factors to the success of an event-based political attractiveness. For example, the "light cluster" around the Festival of Lights in Lyon developed an expertise in lighting. This cluster federates manufacturers, laboratories, designers, and distributors of electricity in the area.

The city of Marmande (France, 34800 residents) is very famous for Garorock (one of the most attractive Rock Festival in France). With the support of their agglomeration (Val de Garonne), they created an event called Garocamp before the opening of the festival. This event focuses on the business of new technologies (digital, cashless, beacons) that are developed to modernize festivals. The festival is a laboratory for all these innovations. The city aims at becoming a reference in this technology. This could lead to an event constellation around new digital technologies for event's organizers and territorial managers.

\section{Interactions for a Long-term Attractiveness 4.1 Case Studies}

We analyzed three different territorial contexts to study the interactions between the identity and image of places.

In the first case, the place is a small size territory. The identity of the place is associated with the event. The name of the place is associated with the name of the event. Place attractiveness is due to the event image. The image of the place is dependent on the event, for example, the festival Jazz in Marciac (France), Coachella in Indio (California), the Glastonbury Festival (England). These places can face difficulties to generate benefits for their place outside of the time of the event. In the second case, the place is a reputed for its event but has a strong identity.

The place identity is strong and independent from the event. The event contributes to the attractiveness of the place on a short-time period, but the place also has its attractive assets all along the year, for example, Berlin and its Berlinale, Cannes and its Festival, Venice and its Mostra. In the third case, the place has a neutral identity or is willing to change its image. These places have a weak identity associated with the nature of events (sports, culture, leisure). Attracting or creating these events is a way to shape a new identity and image of the place.

For instance, events such as the Rugby World Cup in Cardiff (1999), the Olympic Games of Barcelona (1992), the European Capitals of Culture (Glasgow 1990, Lille 2004, Marseille Provence 2013) can be a catalyst for change. For Glasgow, the media coverage before and after 1990 (European Capital of Culture) reflects this improvement (Garcia, 2005). Glasgow became a brand image to attract tourists and investors (Jeannier, 2008). The number of positive reports on the image of the city has increased by over $17 \%$ its number of tourists of $25 \%$ between 1991 and 1998 (Garcia, 2005). The strong positive relationship between tourism, culture, and image of the place. Marseille-Provence being European Capital of Culture wanted to change its image. As a result, in the survey conducted after the year 2013, $85 \%$ of respondents consider that Marseille Provence 2013 strengthened the cultural dimension of the place and that the event broadcasted a positive image of the territory for $80 \%$ of the respondents. It can be a catalyst for change through the urban development of "flagship projects" (Bianchini et al., 1992). In Cardiff, the Millennium Stadium (72 500 seats) built for the world cup of rugby in 1999 was at the heart of the metropolitan renewal strategies. Tourist stays have been increased tenfold, the number of active residents increased by $19 \%$ after this event (Gras, 2007).

If the event is dependent or independent from the territory, the interactions with the identity and the image would be different. Some events can be anchored and dependent on the place where it takes but can be "exported". The exportation of an event out of its territory is a way to promote the identity and image of the territory, for example, the Festival of Lights was "exported" to Dubai, Helsinki, London.

\subsection{Factors of a Long-term Attractiveness}

As events are by nature ephemeral, how can we maintain the place attractiveness through events over the long term? In order to create positive interactive effects between events and places, we identified some key critical factors for the success of an event-based political attractiveness.

First, the inclusion of stakeholders into the governance of project seeks to foster synergies between the private and public sector. It is an opportunity for small and medium territories to emancipate from 
hierarchical inheritance and to change their image as we observed for Marseille and Glasgow.

Then, an event can be tailored to the needs of the place and can maintain an image. The city of Lille launched the event Lille 3000 created a dynamic with the regular organization of the cultural event. The event is a continuation of Lille European Capital of Culture 2004 in a smaller scale (Liefooghe 2010). Lille 3000 takes place every two years to keep the European city of culture effect and to develop cultural events according to the needs of the territory.

Finally, the development of a community unity, mega-events are not just place marketing and may be seen as part of the process of building national identity (Roche 2000, 2008; Getz, 2008). The impact of the events can be reinforced if they are in coherence with the identity of the place. The promotion of events in coherence with the territorial identity develops a sense of belonging to the territory especially if the event is linked to a local product or a cultural aspect of the place. Festivals develop the sense of community and place by reflecting and determining their image and identity (Derett, 2003, 2008). Nevertheless, a paradox exists between the importance of local identity by its function of differentiation and distinction and some local logistics services that must comply with international standards. Quality becomes a critical issue for territorial attractiveness policies.

These key factors in relation to the place image and identity will contribute to the development of the place capacity to sustain different activities in relations to the event.

\section{Conclusion}

A medium-long term vision allows us to analyze the interactions between events and place attractiveness. The study of not only the economic effects in a place marketing approach helps us to understand the reciprocal relationship between identity, image and event constellations.

Over the long term, interactions of image and "event constellations" may transform the territorial identity. Cluster creations and eco systems around an event and a theme (Lumière in Lyon, Mobile telephony in Barcelona) can change the identity of a territory by shaping its image, its infrastructure, and local constellations.

The analysis of the self-sustained nature of these relations can help us to foster global attractiveness. A more transversal approach of events can improve the territorial strategy to boost global and long term attractiveness. The "Marketing" of the place (Management of Place Marketing) could be better with this framework: understanding what goes beyond short-term economic impact to foster long-term positive interactions and endogenous development.

\section{References:}

- Alaux C., Gayet J., (2016), Manifeste de la Chaire ANMT, Christophe Alaux et Place Marketing trends, Joël Gayet, Chaire Attractivité et Nouveau Marketing Territorial, IMPGT, AixMarseille Université.

- Alaux C., Serval S. et Zeller C. (2016), Le marketing territorial des petits et moyens territoires : identité, image et relations, Gestion et management public, Vol.4, $\mathrm{n}^{\circ} 2$.

- Arnaud C (2011), Les évènements culturels, catalyseurs d'un management dans la proximité. Le cas du territoire de la Communauté du Pays d'Aix, Ena, Rabat Maroc, 13 et 14 octobre
2011 « Gouvernance, Développement Territorial et Culture » Med 4 Quatrième Dialogue Euro Méditerranéen de Management Public

- Arnaud C. (2012), Approche fonctionnelle et dynamique du portefeuille territorial d'évènements culturels: manager la proximité pour une attractivité durable du territoire, Thèse de doctorat en Sciences de gestion, sous la direction de Robert Fouchet et de Edina Soldo, à Aix Marseille dans le cadre de l'Ecole Doctorale Sciences Economiques et de Gestion d'Aix Marseille.

- Arnaud C., Gomez-Colombani A., Olivaux M., Fouchet C., (2014) « Enjeux et dynamique de la gouvernance d'un mega-évènement culturel. Approche longitudinale de Marseille Provence 2013, Capitale européenne de la culture », actes colloques airmap

- Arnaud C., Soldo E., (2013) « Le portefeuille territorial d'évènements culturels (PTEC): nouvelle modalité de gestion de l'offre d'évènementiel culturel pour un management stratégique des territoires ", AIMS, 12ème conférence de management stratégique.

- Barget E., Gouguet J-J., (2010), L'accueil des grands événements sportifs: quel impact économique ou quelle utilité sociale pour les régions? L'exemple de la coupe du monde de rugby 2007 en france. Région et Développement $\mathrm{n}^{\circ}$ 31-2010

- Barthon C., Garat I., Gravari-Barbas M. et Veschambre V, L'inscription territoriale et le jeu des acteurs dans les événements culturels et festifs: des villes, des festivals, des pouvoirs, Géocarrefour, Vol. 82/3 |2007, 111-121.

- Cartier A, Morales Y, « Événementiel sportif et attractivité urbaine et touristique des territoires», Téoros 33, 1| 2014

- Casteigts M. (2003), « Le management territorial stratégique », in Sedjari A., Gouvernance et conduite de l'action publique au 21 ème siècle, pp.287-314, coll. Espaces et territoires, éd. L'Harmattan, Paris.

- Castells, M. (1989), The informational city: Information, technology, economic restructuring and the urban-regional process. Oxford: Blackwell.

- European Place Marketing Institute. (2015). Best Place, Place Marketing \& Branding Manifesto

- Evans, G. (2003) Hard-branding the cultural city-from prado to prada. International Journal of Urban and Regional Research, 27(2), pp. 417-440. Retrieved from SCOPUS database. Crossref

- Florida, R. et I. Tinagli (2004), Europe in the Creative Age, Demos/ Université Carnegie Mellon, Londres.

- Florida, R.L. (2002), The Rise of the Creative Class, and How It's Transforming Work, Leisure, Community and Everyday Life, Basic Books, New York.

- García, B. (2001) 'Enhancing sports marketing through cultural and arts programmes: Lessons from the Sydney 2000 Olympic Arts Festivals', Sport Management Review, vol. 4, no. 2, pp. 193-220. $\underline{\text { Crossref }}$

- García, B. (2002) Towards a Cultural Policy for Great Events: Local and Global Issues in the Definition of the Olympic Games Cultural Programme: Lessons from the Sydney Olympic Arts Festivals, 1997-2000. Unpublished doctoral thesis, Universitat Autònoma de Barcelona.

- García, B. (2004) Cultural policy and urban regeneration in western European cities: Lessons from experience, prospects for the future. Local Economy, 19(4), pp. 312-326. Crossref

- García, B. (2004) Urban regeneration, arts programming and major events: Glasgow 1990, Sydney 2000 and Barcelona 2004. International Journal of Cultural Policy, 10(1), pp. 103- 118. $\underline{\text { Crossref }}$ 
- Getz D. (2008) Progress in Tourism Management Event tourism: Definition, evolution, and research, Haskayne School of Business, University of Calgary.

- Getz, D. (1991) Festivals, Special Events and Tourism, Van Nostrand Reinhold, New York.

- Gras P. (2007), « Cardiff veut lier développement et grands événements », Géocarrefour [En ligne], Vol. 82/3 | 2007.

- Gravari-Barbas M. (2013), Aménager la ville par la culture et le tourisme, coll. "Ville-aménagement", éditions Le Moniteur, 2013.

- Gravari-Barbas M., Jacquot S. (2007), "L'événement, outil de légitimation de projets urbains : l'instrumentalisation des espaces et des temporalités événementiels à Lille et Gênes", Géo-carrefour, vol 82 (3), p.16

- Hall C.M. (1997), Mega-events and their legacies, in P.E. Murphy (ed.), Quality management in urban tourism, John Wiley, New York.

- Ingallina P., Park J., (2005) « City marketing et espaces de consommation. Les nouveaux enjeux de l'attractivité urbaine ", Urbanisme $n^{\circ} 344$, septembre -octobre 2005.

- Jafari, J. (1988). Tourism mega-events. Annals of Tourism Research, 15, 272-273. Crossref

- Kalandides, A. (2011) 'The Problem with Spatial Identity: Revisiting the 'Sense of Place', Journal of Place Management and Development 4(1): 28-39. $\underline{\text { Crossref }}$

- Kavaratzis M., Hatch M-J. (2013), The dynamics of place brand an identity-based approach to place branding. Marketing Theory March 2013 vol. 13no. 1 pp.69-86. Crossref

- Landry, C., Bianchini, F., 1995, The Creative City, Londres, Domos/Comedia, 1995, $60 \mathrm{p}$.

- Liefooghe C., 2010, Lille 2004 Capitale européenne de la culture, ou la quête d'un nouveau modèle de développement, Méditerranée, Université de Provence, $\mathrm{n}^{\circ} 114$.

- Médiamétrie Rapport (2015) Salons et Foires en France: un puissant outil de développement pour les entreprises Ministère de l'Économie au travers de la Direction Générale des Entreprises et par Unimev, la CCI Paris Île-de-France et le Comité des Expositions de Paris.

- Ritchie J. R. B. (1984), “Assessing the impacts of hallmark events: Conceptual and r- Ritchie J. R. B., Crouch G. I. (2000), "The competitive destination: A sustainability perspective", Tourism Management, vol.21, pp.1-7.

- Roche, M. (2000) Mega-events Modernity: Olympics and Expos in the Growth of Global Culture, Routledge, London. British Journal of Sociology, vol.43, pp.563-600.

- Scott, A. (2010) Cultural economy and the creative field of the city. Geografiska Annaler: Series B, Human Geography, 92(2), pp. 115130. Crossref

- Siegfried J., Zimbalist A., (2000) "The Economics of Sports Facilities and Their Communities", Journal of Economic Perspectives, 14:3, pp.95-114. $\underline{\text { Crossref }}$

- Soldo E. et al. (2013/4), « L'évènement culturel en régie directe, un levier pour l'attractivité durable du territoire? Analyse des conditions managériales de succès », Revue Internationale des Sciences Administratives (Vol. 79), p. 779-799.

- Soldo E., Arnaud C., Keramidas O. (2011), « Le management de l'évènement culturel, déterminant de l'attractivité durable des territoires : proposition d'un 'modèle de régie'. Le cas de la saison culturelle 'Picasso-Aix 2009' sur le territoire de la Communauté du Pays d'Aix », Revue Internationale des Sciences Administratives, reviewing première version.
- Tajfel H., Turner J.C. (1979). An integrative theory of intergroup conflict. In S. Worchel and W. Austin (Eds), The social psychology of intergroup relations (pp. 33-48). Pacific Grove, CA/ Brooks/Cole. 